DIGITAL COMMONS
@ UNIVERSITY OF SOUTH FLORIDA

Volume 11

Issue 1 Summer 2021

\section{ABO: Interactive Journal for \\ Women in the Arts, 1640-1830}

\title{
Review of Writing and Constructing the Self in Great Britain in the Long Eighteenth Century, edited by John Baker, Marion Leclair, and Allan Ingram
}

Kelly J. Plante

Wayne State University, kellyjplante@wayne.edu

Follow this and additional works at: https://digitalcommons.usf.edu/abo

Part of the Feminist, Gender, and Sexuality Studies Commons, History of Philosophy Commons, Intellectual History Commons, Literature in English, British Isles Commons, and the Philosophy of Mind Commons

\section{Recommended Citation}

Plante, Kelly J. (2021) "Review of Writing and Constructing the Self in Great Britain in the Long Eighteenth Century, edited by John Baker, Marion Leclair, and Allan Ingram," ABO: Interactive Journal for Women in the Arts, 1640-1830: Vol.11: Iss.1, Article 19. http://doi.org/10.5038/2157-7129.11.1.1251

Available at: https://digitalcommons.usf.edu/abo/vol11/iss1/19

This Reviews is brought to you for free and open access by Digital Commons @ University of South Florida. It has been accepted for inclusion in ABO: Interactive Journal for Women in the Arts, 1640-1830 by an authorized administrator of Digital Commons @ University of South Florida. For more information, please contact digitalcommons@usf.edu. 


\title{
Review of Writing and Constructing the Self in Great Britain in the Long Eighteenth Century, edited by John Baker, Marion Leclair, and Allan Ingram
}

\author{
Abstract \\ Baker, Marion Leclair, and Allan Ingram. Written by Kelly Plante.

\section{Keywords} \\ history of the self, philosophy of the self, the eighteenth-century self \\ Creative Commons License \\ (c) (1) (9)
}

A review of Writing and Constructing the Self in Great Britain in the Long Eighteenth Century, eds. John

This work is licensed under a Creative Commons Attribution-Noncommercial 4.0 License 
John Baker, Marion Leclair, and Allan Ingram, eds. Writing and Constructing the Self in Great Britain in the Long Eighteenth Century. Manchester University Press, 2019. 282 pp. ISBN 9781526123367.

\section{Reviewed by Kelly Plante Wayne State University, USA}

Writing and Constructing the Self in Great Britain in the Long Eighteenth Century, edited by John Baker, Marion Leclair, and Allan Ingram, is a welcome contribution to the history and philosophy of the self and long eighteenth-century literary/cultural studies fields. Foucault's Technologies of the Self lecture series and Stephen Greenblatt's successive Renaissance Self-Fashioning set the stage for a proliferation of scholarship on self-fashioning in literary/cultural studies fields, long eighteenth-century studies not excepted. There are not enough such focused, book-length studies on the self in the long eighteenth century, given that it includes the Enlightenment and Romantic movements that birthed the modern sense of self as we know it.

An output of the Institut du Monde Anglophone's 2013 international one-day conference in Paris, Writing and Constructing the Self presents twelve essays that work individually and as a collective - one of the book's major themes. The collection illustrates in theory and praxis one of the introduction's most salient points: that although neoliberalism renders collective bargaining and action toward social justice difficult, co-operation between selves is still possible and necessary. Uniting twelve essays informed by John Locke's An Essay Concerning Human Understanding, the volume is a prism of selves. In it, Locke's construction of the self reflects and refracts the multiplicity of selves that are each individual essay. As a result, the collection can permeate the more cis/malecentered history and philosophy of the self field, increasing representation for the long eighteenth century and for women.

The introduction demonstrates the importance of studying the self that has arisen from seventeenth- and eighteenth-century political, religious, cultural, and economic revolutions. The volume creates "a narrative, a patchwork chronicle, a multilogue that will illustrate the diversity, resilience and unity of the notion of the self" (3). The Western concept of the self-itself a "self" in the Lockean sense of an identity preserved, if mutated, over time - operates as, the editors argue, both "refuge" and "mask" or "persona" (3). As a "refuge," the self offers an interior retreat for spiritual (interior) development. As a "mask" or "persona," the self assists one in navigating the (exterior) community. Such careful distinctions are valuable. "The self" is an unwieldy semantic field, which this book's 
illumination of the self and its interior and exterior functions helps the reader to navigate. The shared vocabulary aids in distinguishing between the soul, the individual, and the self. In bringing into focus such studies as Raymond Martin and John Barresi's The Rise and Fall of Soul and Self: An Intellectual History of Personal Identity, which makes similar distinctions, this volume helps readers comprehend more complex ideas such as the "plurality of the self," or the divided self (170).

The book's three parts- "Early Modern Selves and the Reason v. Passion Debate," "Self-exploration in the Age of Reason: Division and Continuity," and "Romantic Wanderings: The Self in Search of (Its) Place"—-stage a matrix of selfconcepts. In part one, Laura Alexander's essay on Anne Killigrew, Regina Maria Dal Santo's on sermons, Jeffrey Hopes's on Mandeville and Hutcheson, Orla Smyth's on Eliza Haywood, and William Flesch's on Joseph Addison's and Samuel Johnson's dueling interpretations of the death of King Lear's Cordelia stage the gendered nature and implications of the early modern self in "the Reason v. Passion Debate." Part two builds on the gendered impact of bifurcating "Reason v. Passion" in the "Age of Reason," following up Clark Lawlor's essay on Pope's Dunciad with Ingram's essay on "Johnson, Boswell and Representations of the Self," which shows the self, bifurcated in "two minds." The "female self" reappears in Barbara Puschmann-Nalenz's "'The Place where my Present Hopes Began to Dawn': Space, Limitation and the Perception of Female Selfhood in Samuel Richardson's Pamela." Gioiella Bruni Roccia's "The Discursive Construction of the Self in Shaftesbury and Sterne: Tristram Shandy and the Quest for Identity" transitions to part three, which contains chapters by Laura Quinney and Eva Antal on gnostic selves versus souls in Blake and Wordsworth and "Burke's (Miltonic) reading of the sublime." The editors reiterate their focus on the shared purpose stated in the introduction, of producing a conception of the modern "self" that can (still) align individuals toward social justice, by ending the volume on the note of "Self and community in radical defence" in Rachel Rogers's essay on the French Revolution.

While each essay reflects the book's prismatic vision, especially valuable is Smyth's essay, "Fashioning Fictional Selves from French Sources: Eliza Haywood's Love in Excess, " which sheds new light on the self as portrayed in Haywood's amatory fiction, with implications for her writing in other genres as well. The essay grounds Haywood in the history-of-the-self discourse, using Locke as a touchstone. Smyth illuminates Madame de La Fayette's influence on Haywood and her eighteenth-century readership. Building on Ros Ballaster's Seductive Forms: Women's Amatory Fiction from 1684 to 1740, Smyth argues that "For anyone interested in charting early modern changes in the conception of the self, the short novels of this period are an obvious place to look" and that "the 
language of the self ... was much richer than any single philosophical source [i.e., Cartesian rationalism] could provide" (90). This argument is compelling and important; it values women's amatory fiction over male-penned philosophical treatises. Smyth's essay opens up new possibilities for scholars to explore the self in its full capacity at this critical juncture by cementing Haywood in her hardearned place as a philosopher of the self, resuming her Gentleman's Magazinegranted position as the eighteenth century's "fair philosopher." The juxtaposition of this essay with Puschmann-Nalenz's essay on Pamela within the same collection lays bare the appropriation of Haywood's methods that made Richardson the successful writer that he was. Pamela's place-driven introspection and middle-class interiority would not have been recognizable without the already-existing vocabulary afforded to eighteenth-century readers by Haywood and Madame de La Fayette. Haywood appears again in Lawlor's chapter on Pope's Dunciad. Here, Lawlor argues that Pope presents in The Dunciad a "grotesque matrix" of "anti-selves," which embody various threats to his identity as a male writer (18). Building on the scholarship of Catherine Ingrassia, Lawlor writes that Haywood "brought together issues of female authorship and the capitalistic book market" and "provides the direct anti-self through which Pope can reveal his own, apparently deformed, physical self” (131). In a similar fashion, Laura Alexander demonstrates how, like Pope, Killigrew uses other women writers such as Aphra Behn and Delarivier Manley as a backdrop against which to define herself as a "spiritual wit" as opposed to a courtly or sexual one. Both essays highlight the key role that amatory novelists such as Haywood, Behn, and Manley play in writing and constructing the self in Great Britain in the long eighteenth century — as writers and literary/public figures.

No volume can cover it all, and if Writing and Constructing the Self foregrounded the self at every intersection, it would explode its 273-page boundary; the valuable insights it offers would be less visible and effective. Any such volume must "foreground" some selves over others, which the editors acknowledge. (For more on the importance of "foregrounding" for writing and constructing the self, see pages $4,8,19,80$, and 229.) While "the female self" occupies the foreground - again an overdue and much welcomed trend for the history and philosophy of the self - the volume lacks representation of queer selves, Black, indigenous, and colonized selves. The index, though, points to the pages on sexuality so that readers can trace the theme throughout the book and analyze connections; Puschmann-Nalenz's chapter on Pamela shows a self threatened by the "master's" egoic abuse of power and illuminates Pamela's interior and exterior capacity to survive; and Roccia's essay on "Tristram Shandy and the Quest for Personal Identity" provides a script for recovering the fractured self. 
Writing and Constructing the Self contributes an important critical framework and serves as a touchstone for other such focused studies of the eighteenth-century self, and selves. Scholars interested in tracing the influence of Locke's Essay and/or teaching the self to undergraduate or graduate students would find this book valuable, due to its division into parts and chapters that serve as discussion starters. The book's foregrounding of women such as Haywood and Madame de La Fayette and their characters, alongside male-penned "female selves," renders it an important contribution to feminist literary/cultural studies. 